\title{
Article \\ Effects of Adjacent Land Use Types on the Composition of Vascular Flora in Urban Forest Ecotones in the Southern Poland
}

\author{
Beata Fornal-Pieniak $^{1, *(\mathbb{D})}$, Barbara Żarska ${ }^{1}$ (D) and Marcin Ollik $^{2}$ (D) \\ 1 Department of Environmental Protection and Dendrology, Institute of Horticultural Sciences, \\ Warsaw University of Life Sciences-SGGW, 02-787 Warsaw, Poland; barbara_zarska@sggw.edu.pl \\ 2 Department of Biometry, Institute of Agriculture, Warsaw University of Life Sciences-SGGW, \\ 02-787 Warsaw, Poland; marcin_ollik@sggw.edu.pl \\ * Correspondence: beata_fornal_pieniak@sggw.edu.pl
}

Citation: Fornal-Pieniak, B.; Żarska, B.; Ollik, M. Effects of Adjacent Land Use Types on the Composition of Vascular Flora in Urban Forest Ecotones in the Southern Poland. Forests 2021, 12, 1440. https:// doi.org/10.3390/f12111440

Academic Editor: Bruce D. Clarkson

Received: 19 August 2021

Accepted: 20 October 2021

Published: 22 October 2021

Publisher's Note: MDPI stays neutral with regard to jurisdictional claims in published maps and institutional affiliations.

Copyright: (c) 2021 by the authors. Licensee MDPI, Basel, Switzerland. This article is an open access article distributed under the terms and conditions of the Creative Commons Attribution (CC BY) license (https:/ / creativecommons.org/licenses/by/ $4.0 /)$.

\begin{abstract}
The purpose of the research was the recognition of edge effects regarding similarities and differences of vascular flora in undergrowth layers in the urban forest ecotones. Four types of urban forest neighborhoods were analyzed: ecotones adjacent to the manor park, the agriculture field, housing estates and the road. The plant compositions in the forest ecotones were compared with the plant compositions in the urban forest interior and the forest nature reserve. The phytosociological type of studied forests was a subcontinental oak-hornbeam one (Tilio-Carpinetum). Diagnostic plant species (e.g., characteristic) for forests from the non-diagnostic ones were identified. Forest consistent plant species dominated in the ecotone adjacent to the manor park and in the interior of urban forests too, but the best conditions for these plants were inside the forest nature reserve, where native consistent forest plants showed the highest dominance when comparing all studied areas. A higher anthropogenic pressure from the adjacent areas results in supporting the growth of inconsistent plant species in the forests, and these plants are mostly represented by plants belonging to grass and synanthropic communities. Another conclusion drawn from our research is that the protected forest, represented by a nature reserve in the city, provides better "shelter" for native forest plants than the urban forest without any protection. Ultimately, a permanent challenge is to achieve and maintain the balance between nature and the impact of anthropogenic activities on urban forests in the city. The high quality of green areas, biodiversity, including forests, implicates possibilities of sustainable development in cities. The research results will be useful for local urban planners and ecologists during their work on strategies of city development, including shaping of green infrastructure.
\end{abstract}

Keywords: ecotones; vascular flora; urban forest; land use; city

\section{Introduction}

Urban forests provide numerous benefits, including recreational [1], natural [2], socioeconomic [3], and therapeutic [4-6] ones for the well-being of human life in cities [7-11]. Urban and suburban forests are very important elements in the ecological structure of landscape in Europe [1]. The topic of edge effects in urban forests seems to be underestimated as regards the scale and variety of disturbances caused by an anthropogenic impact. Forests are the basic sources for the spreading and colonization of forest and ancient forest species [12-15]. Forest species are sensitive to habitat fragmentation [5], and ancient forest species are proper indicators of natural habitat continuity. These plants are diagnostic for old woodlands (between 100-200 years old) and ancient woodlands (more than 200 years old) [16]. The urbanization process makes it difficult to protect natural habitats as forests. Moreover, it is still observed that the number of anthropogenic elements increases, for example housing and roads in urban and suburban areas in Europe [17]. Major urbanization factors cause biodiversity and habitat loss, habitat degradation and a growing penetration of species from non-forest surroundings, including alien species. Usually, the most vulnerable and sensitive to exposure and degradation is vegetation [18-20]. Plant species, mostly 
herbs, are very dynamic and they are proper indicators of habitat transformation [21]. Trampling can cause extensive damage to soil and undergrowth layer in the forests [22]. Research on the edge effects and widths of forest edge zones in different types of forest ecosystems have been frequently conducted since the 1970s of the 20th century, generally, since the fragmentation of landscape has started to be considered a serious threat to the natural environment $[23,24]$. These studies have mainly been conducted in the forests in rural landscapes (rarely in urban and suburban ones) in many countries using various criteria (climatic, floristic/phytosociological, fauna, including avifauna).

Ecotones, interpreted differently in the literature, are generally understood as contact zones between two different ecosystems or biocenoses, expressed by greater or lesser changes in microclimatic conditions, species composition and structure [25].

The forest edge is the marginal forests strip where ecotone influences from significantly different ecosystems adjacent to forests (e.g., agriculture field, meadow, road, housing estate) cause various changes in microclimate, vegetation and fauna-in comparison with conditions occurring in interiors of big-sized forest complexes. The forest-size category and adjacent land use were the most important factors determining forest species richness and composition; penetration by humans had the crucial meaning: forests adjacent to crops were less threatened by percolation of non-forest species than forests adjacent to urban sites $[26,27]$. Undergrowth vegetation was investigated in urban forests in Helsinki and the spatial range of edge effects was evaluated up to $50 \mathrm{~m}$ towards forest interiors, using criteria of trampling and vegetation changes in marginal zone of forests [28]. According to [27] synanthropic plant species richness in the studied forests was higher in small forests than in large ones, and it declined with increasing distance from the forest boundary towards the interior. Furthermore, the richness of rare forest species was lower in small patches than in large forest complexes.

Applying floristic and phytosociological criteria to recognize edge effects in the forests in rural landscape, average widths of forest marginal zones were marked out where changes of vegetation were observed in different types of forests communities in lowlands in Central Poland (European Lowland), for example from $20 \mathrm{~m}$ in alder (Ribeso nigri-Alnetum) to $100 \mathrm{~m}$ in oak-hornbeam forests (Tilio-Carpinetum) [29,30]. Other authors [31] proposed that the threshold value of spatial extend of edge and trampling effects should be assumed as at least $160 \mathrm{~m}$ width for needs of urban forestry and spatial planning to protect and support forest interiors in indigenous species survival. Suggestions that the widths of ecotones where plant species could be seriously threatened by anthropogenic influence range from a few meters up to $200 \mathrm{~m}$ in forests have been made [32,33]. Different types of land use adjacent to forests should be considered as the main factor with impact on the plant species composition in forest ecotones [34,35]. Diagnosis and minimization of negative impact of different sources adjacent to the forests are important for the conservation and management of forest ecosystems [36-39]. Relatively few studies in forests remnants in urban and suburban landscape have been carried out [30,31].

The purpose of the research was the recognition of edge effects regarding similarities and differences of vascular flora in undergrowth layers. The urban forest ecotones were distinguished, depending on surrounding types of land use. The plant compositions of forest ecotones with urban forests interiors and forest nature reserves were compared. We aimed to check plant species composition from the edge to the forest interior up $200 \mathrm{~m}$ as well as in forest interiors; in ecotones, more plants related to the anthropogenic pressure than inside the forests could occur [34,35].

A greater occurrence of species inconsistent with forest habitats in forest ecotones close to housing estates, road and agriculture field than in the forest ecotones adjacent to manor parks and also in forest interiors is expected (hypothesis 1). Ecotones contain diagnostic (indicator) plant species, depending on types of land use adjacent to the forest (hypothesis 2). More forest vascular plants are diagnostic for stability of Tilio-Carpinetum communities in forest nature reserve than inside urban forests not being protected and in ecotones (hypothesis 3). Based on our research results, we intend to assess the scale of 
anthropogenic pressure on the composition of vascular plant species located in protected and non-protected forests in the city. This issue has a more general application, mostly connected with the problem of climate change. Such knowledge regarding the level of forest ecotones disturbances and forest ecosystems is important for urban development managers and architects: how to shape land use and forests surroundings to minimalize the negative impact on native plants and biodiversity.

\section{Methodology}

\subsection{Study Areas}

The research was carried out in 2020 in two forests: one urban forest and one nature reserve located in the northern part of the city of Tarnów in southern Poland. The St. Martin Mountain urban forest, located on one of the Tarnów's hills, covers 30.23 ha $\left(49^{\circ} 59^{\prime} 23^{\prime \prime} \mathrm{N}\right.$ $21^{\circ} 00^{\prime} 20^{\prime \prime} \mathrm{E}$ ). Carpathian beech and oak-hornbeam forest communities are dominating there. The Debrza forest nature reserve with the area of 9.5 ha was established in that area in 1995. The studied plant community in the Debrza nature reserve represents the subcontinental oak-hornbeam forest (Tilio-Carpinetum), with lime tree admixture. The species composition of the tree stand has a natural character (the presence of native species). The Debrza nature reserve is a small, isolated forest complex, predominantly surrounded by agricultural fields and buildings [40] (Figure 1).

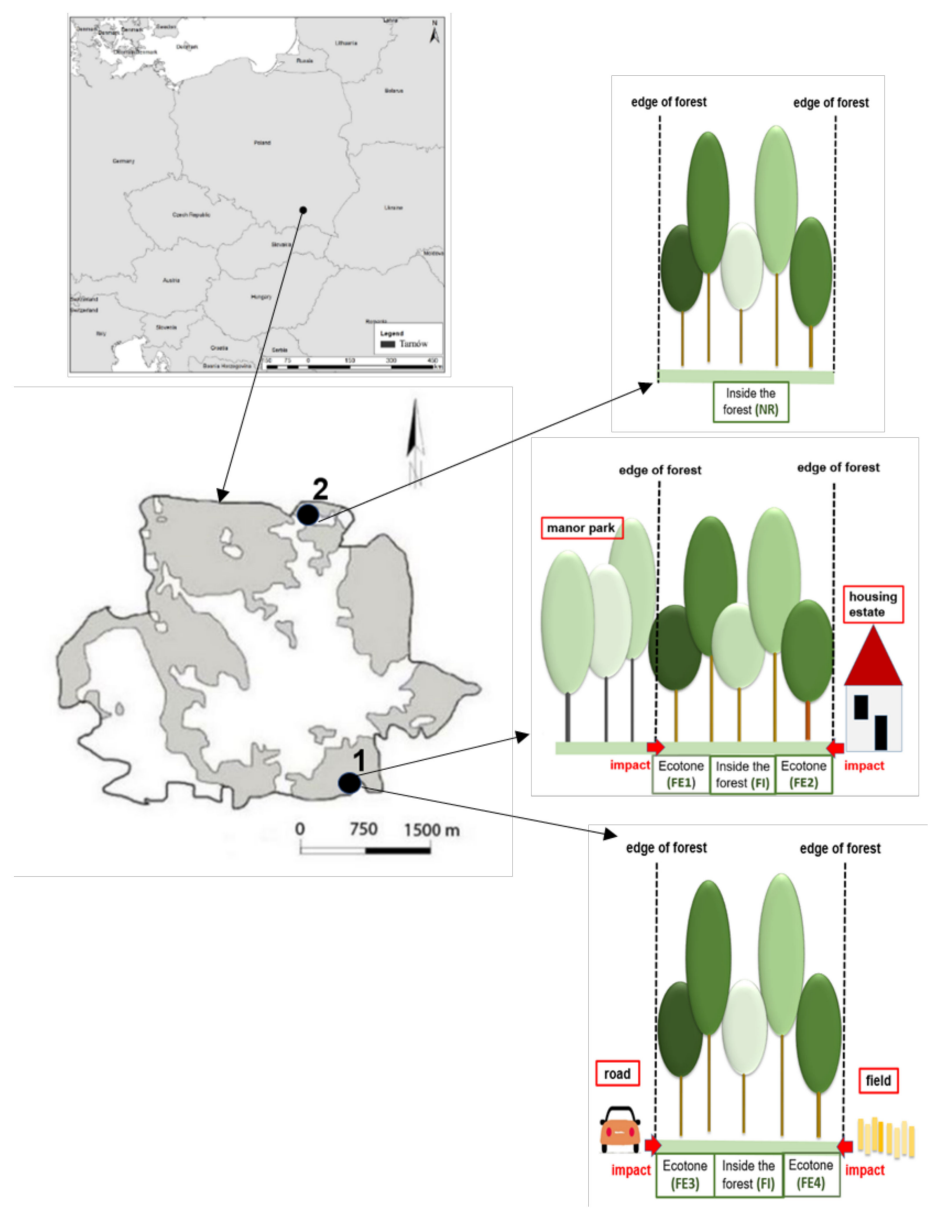

Figure 1. Localization of the city of Tarnów in Poland and study areas—forests (1-urban forest, 2-Debrza forest nature reserve) within Tarnów city borders, with schemes of arrangement research areas: five in urban forest (1) and one in nature reserve (2), FE1-ecotone adjacent to the forest part of manor park, FE2 - ecotone adjacent to the housing estates, FE3-ecotone adjacent to the road, FE4 - ecotone adjacent to the agriculture field, FI-research area inside the urban forest (in forest interior), and NR-research area in the interior of the Debrza forest nature reserve. 


\subsection{Field Research Methods}

The research was conducted in forest ecotones and in the interior of the urban forests in the city of Tarnów, including the Debrza forest nature reserve. In all studied areas, oak-hornbeam forests (Tilio-Carpinetum community), being one of the most valuable forest communities in Poland and also in most of Europe, were chosen for vascular flora research. According to Council Directive 92/43/EEC (Habitat Directive of EU), Tilio-Carpinetum is represented by Habitat Code 9170 [41] (in the European Union all natural habitats and species of flora and fauna important for Europe have individual identification codes and are protected within European Nature 2000 Network on the legal basis of Habitat Directive and Birds Directive).Six research areas were distinguished: five in the urban forest (four ecotones: FE1, FE2, FE3 and FE4, and one area inside this forest: the forest interior: FI) and one research area in the interior of the forest nature reserve (NR) [1]. Study ecotones were chosen depending on different types of land use adjacent to the forest. The first forest ecotone was adjacent to the forest part of a manor park (FE1), the second-to housing estates (FE2), the third-to a local road (FE3), and the fourth — to agriculture field (FE4) (compare: Figure 1). The manor park is the historical area established in the 18th century. Today, it looks like a "forest", because after the second World War, like many other manor parks in Poland, it had no proper management and maintenance, which led to the disappearance of the human-made compositional system, but instead allowed the regeneration of natural flora and vegetation according to the natural potential of the habitat [42,43]. All studied ecotones were located in the southern part of the urban forest, from the edge to the forest inside at the distance up to $200 \mathrm{~m}$. Sixty phytosociological records were compiled in plots of $10 \times 10 \mathrm{~m}$ according to [44] covering the range of ecotone conditions.

The total number of plots (phytosociological records) amounted to 240 in the whole studied ecotones. Research areas were located interior the urban forest (FI) and inside the Debrza forest nature reserve (NR), where 60 plots (phytosociological records) were made in each one. The studied plots of $10 \mathrm{~m} \times 10 \mathrm{~m}$ were located inside the forests at a distance of at least $200 \mathrm{~m}$ from the forest edge and they were also surrounded by Tilio-Carpinetum community. The main criteria for selecting the plots for the phytosociological records were the type of phytocoenosis and well-developed undergrowth layer. The undergrowth layer included trees, shrubs, grasses and herbs up to $40 \mathrm{~cm}$ in height [44]. The identified plant species were grouped according to the degree of inconsistency with the natural habitat and the type of communities: forest, shrub, meadows, trampled and synanthropic communities (according to [41]). Consistent plant species mean native plants, diagnostic for oak-hornbeam habitat (Tilio-Carpinetum) [23]. The number of all species, share of forest plants, number and share of ancient forest species were determined with respect to the undergrowth layer in every plot in the ecotones and the forest interior (altogether, 360 plots). Inconsistent species (e.g., plants that are not diagnostic for Tilio-Carpinetum), plant species belonging to shrub, meadows, trampled and synanthropic communities and accompanying plants were also distinguished according to the classification by [41]. Accompanying plants mean plants that have received phytosociological classification [41]. Apart from that, we distinguished ancient forest plant species, which are very good indicators of the naturalness of a habitat [45].

The list of ancient forest plant species for Poland was used according to [46]. Forest plant species typical for oak-hornbeam forests (Tilio-Carpinetum) were distinguished according to [47].

\subsection{Statistical Analysis}

In order to establish the degree of compliance with the habitat, the following parameters were calculated for each plot: the total number of species, the number and share of species consistent with the habitat (belonging to Tilio-Carpinetum community), the number and share of the ancient forest species.

Mean values of these parameters were compared by Generalized Linear Model (GLM) with one categorical variable (corresponding to one-way ANOVA). As a model function, 
we used Poisson distribution for species numbers and beta distribution for species shares. Additionally, mean species number characteristic for different vegetation types was calculated. Detrended Correspondence Analysis was used to detect species whose presence or absence is characteristic for ecotones. To perform the analysis, the abundance of individual species was transformed from Braun-Blanquet to van der Maarel scale [48].

\section{Results and Discussion}

The total species number differed significantly $\left(p<10^{-4}\right)$ between the interior of the nature reserve, inside the urban forest and in the ecotones. The ecotone adjacent to the forest part of the manor park (FE1) had a significantly lower number of plant species than the interior of the urban forest. However, we were able to detect a higher number of plant species in types of ecotones (FE2, FE3, FE4) other than inside the urban forest. The species number in the interior of the nature reserve was a bit higher than inside the urban forest (Figure 2).

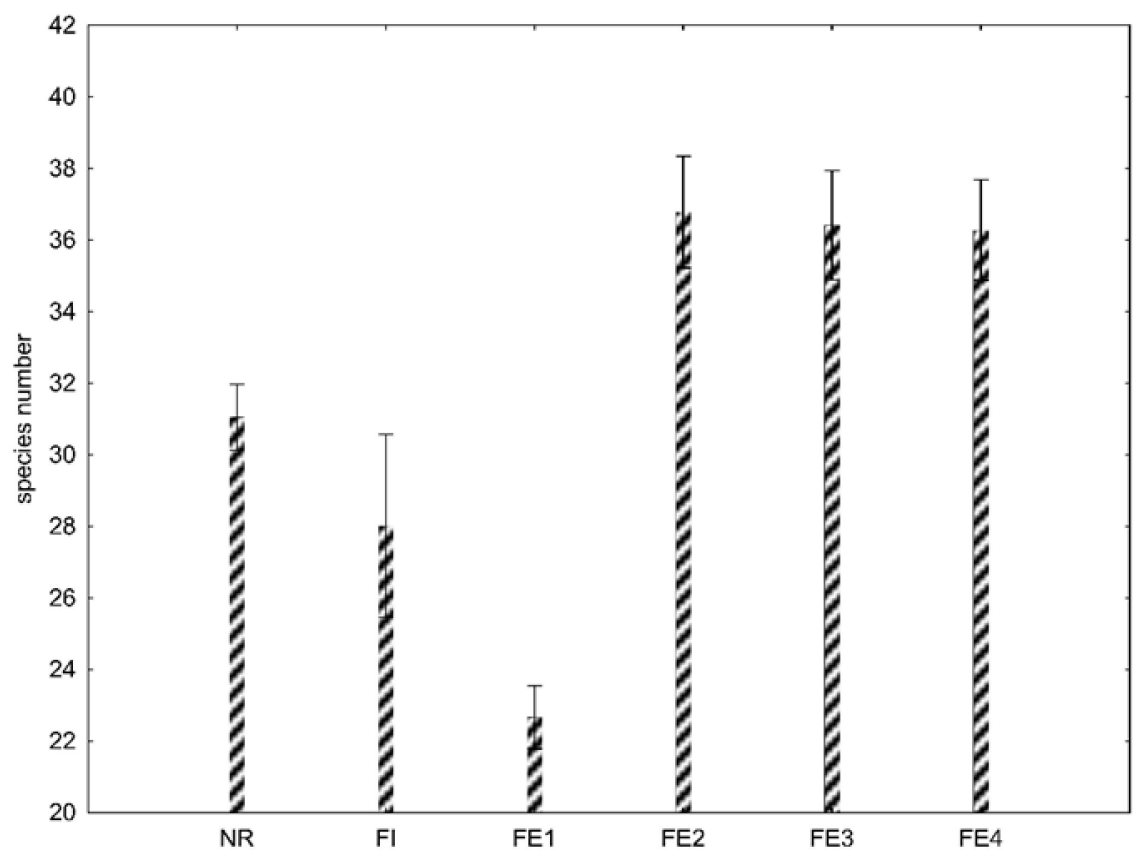

Figure 2. Mean species number in the nature reserve (NR), urban forest inside/interior (FI), forest ecotone adjacent to the forest part of the manor park (FE1), forest ecotone adjacent to housing estates (FE2), forest ecotone adjacent to the road (FE3), and forest ecotone adjacent to the agriculture field (FE4). Error bars show 95\% confidence intervals.

The mean number of species consistent with the habitat was similar in all ecotones and inside the urban forest (about 19) and significantly lower than in the interior of the nature reserve [27] (Figure 3a). It should be noted that species consistent with the habitat accounted for as much as $90 \%$ of all the species in the forest nature reserve. These species also dominated inside the urban forest $(75 \%)$ and in the ecotone adjacent to the manor park $(83 \%)$. In other ecotones adjacent to the field, the road and the housing estates, their share was as low as $52 \%$ (Figure $3 b$ ).

The highest number of ancient forest species was noticed in the interior of the nature reserve [49]. They also constituted the largest part of the species pool there $(72 \%)$. The ancient forest species were less numerous (on average 14-15 species per plot), but still dominated in the species composition (59\%-63\%) inside the urban forest (FI) and in the ecotone adjacent to the forest part of the manor park (FE1), but not in the ecotones adjacent to the housing estates, road and field. On average, 11 species were recorded there, which accounted for $30 \%$ of their total number (Figure 4 ). 


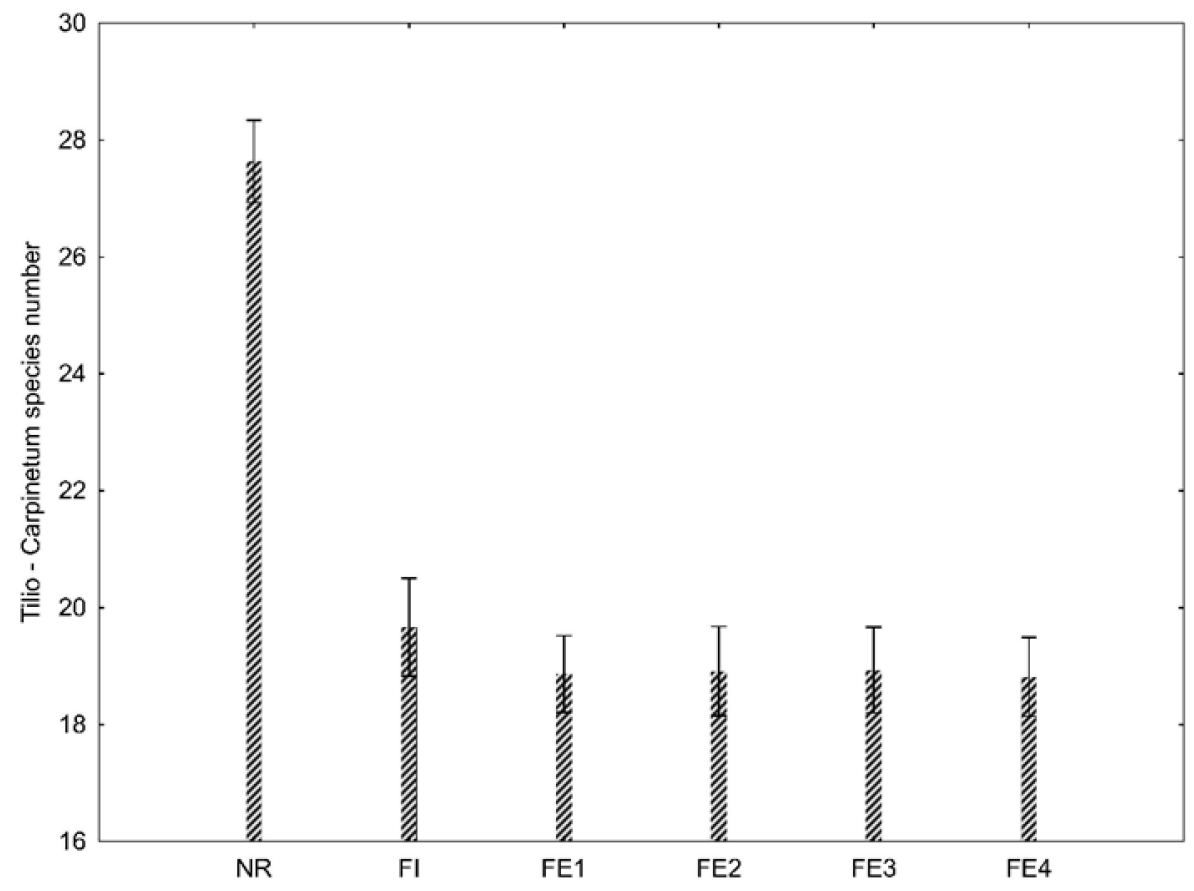

(a)

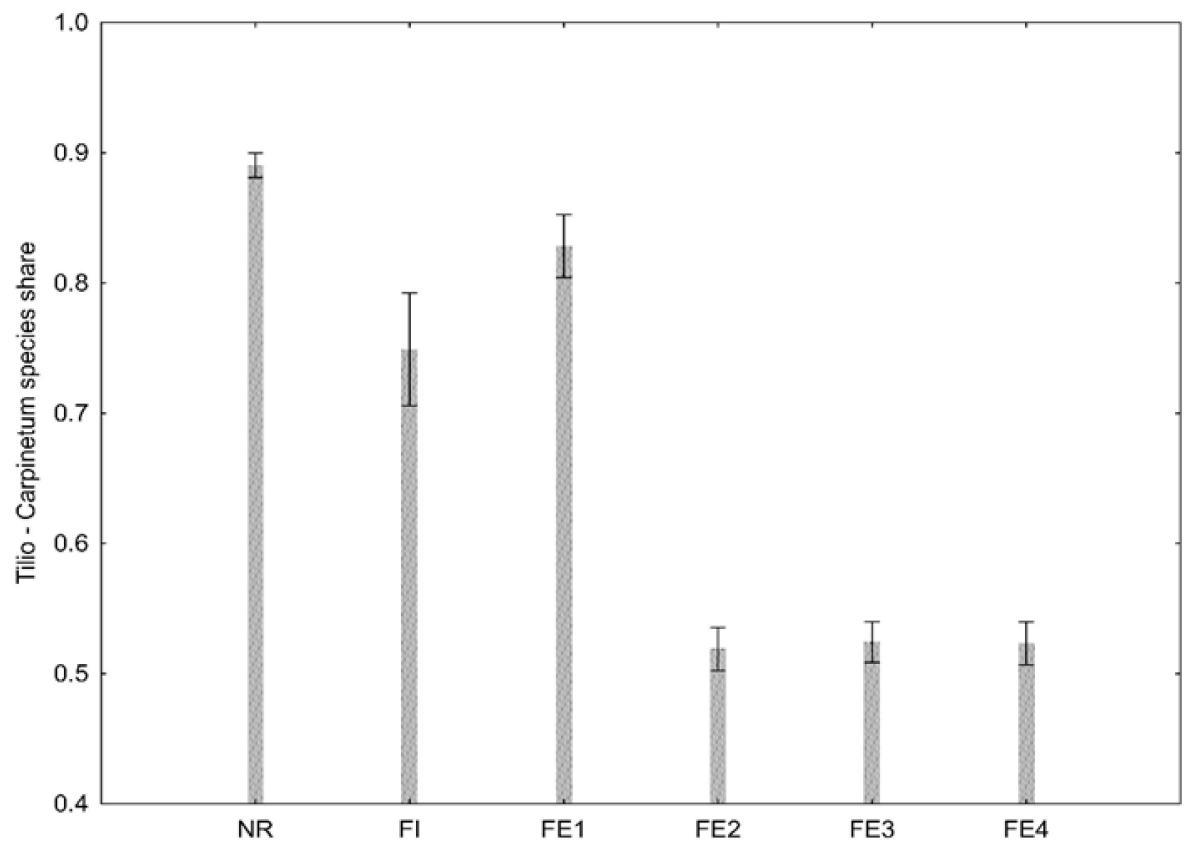

(b)

Figure 3. Mean number (a) and share (b) of species consistent with Tilio-Carpinetum habitat in the nature reserve (NR), forest inside/interior (FI), forest ecotone adjacent to the forest part of the manor park (FE1), forest ecotone adjacent to the housing estates (FE2), forest ecotone adjacent to the road (FE3), and forest ecotone adjacent to the agriculture field (FE4). Error bars show 95\% confidence intervals.

A more precise look on the species composition shows that only forest species with a slight admixture of accompanying species (on average, 3-4) occurred in the forest nature reserve (Figure 5). In the interior of the urban forest and in the ecotones, species characteristic for other types of vegetation were also detected, mainly plant species from synanthropic, 
meadows and trampled communities. They were observed less often in the ecotone adjacent to the manor park (on average, 1.1 and 0.4 species per plot) and somewhat more often inside the urban forest (3.2 and 1.7). However, plant species represented by synanthropic, meadows and trampled communities were more frequent (8.4-9.0 and 4.0-4.4 species per plot) in ecotones adjacent to the housing estates, road and field than inside the urban forest, the nature reserve and the ecotone adjacent to the forest part of a manor park.

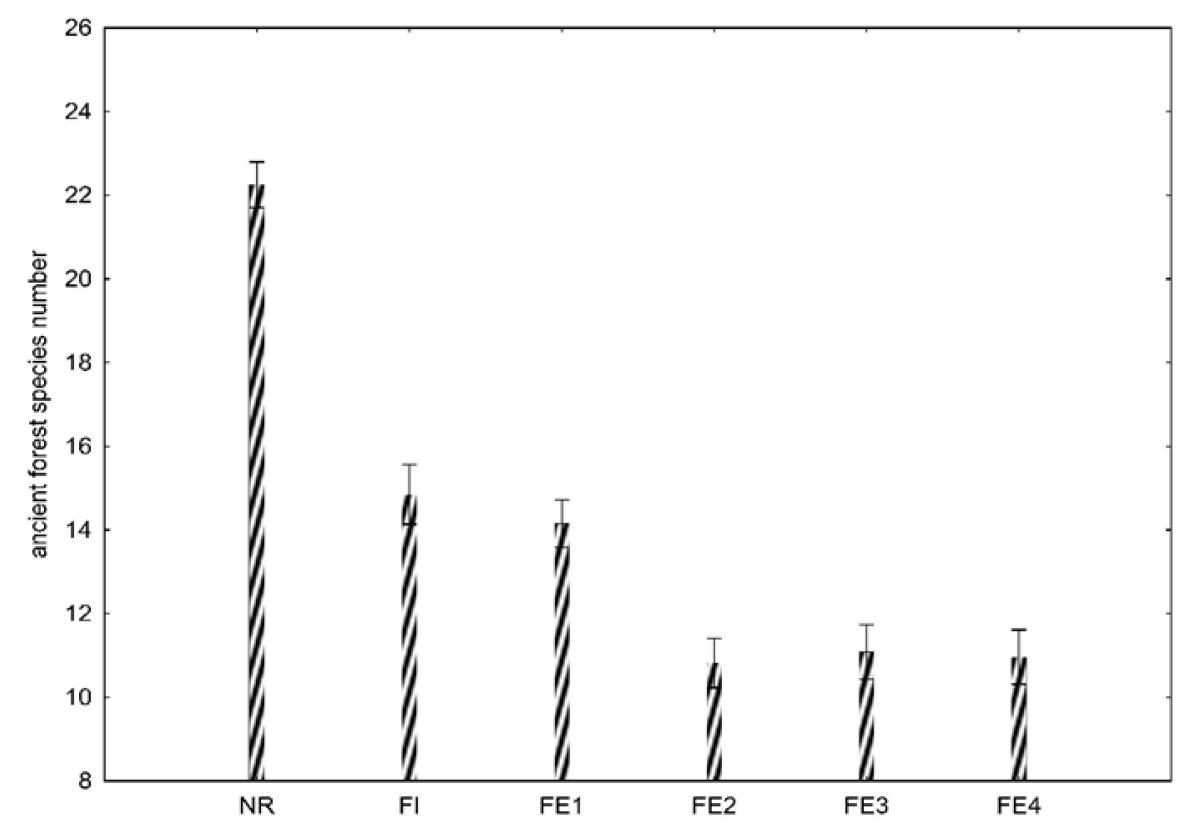

(a)

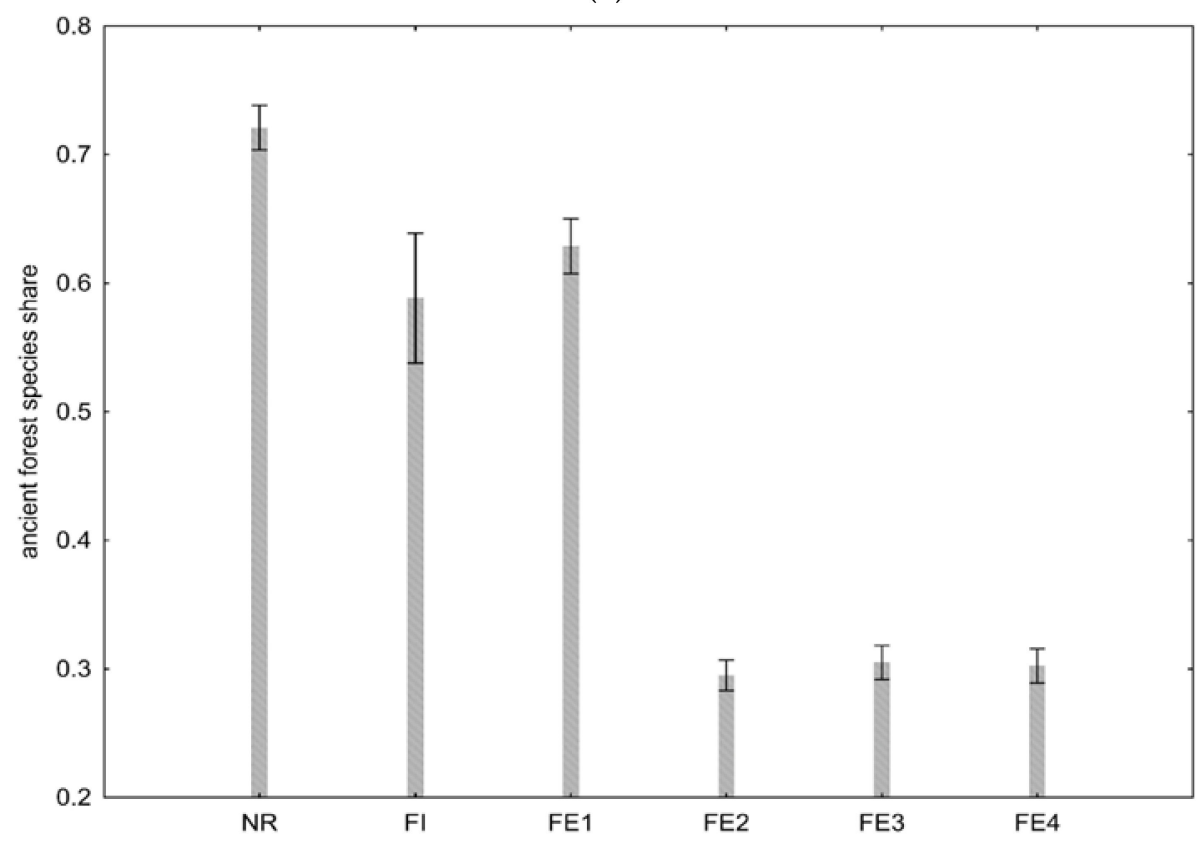

(b)

Figure 4. Mean number (a) and share (b) of ancient forest species in the nature reserve (NR), forest inside/interior (FI), forest ecotone adjacent to the forest part of the manor park (FE1), forest ecotone adjacent to the housing estates (FE2), forest ecotone adjacent to the road (FE3), and forest ecotone adjacent to the agriculture field (FE4). Error bars show 95\% confidence intervals. 


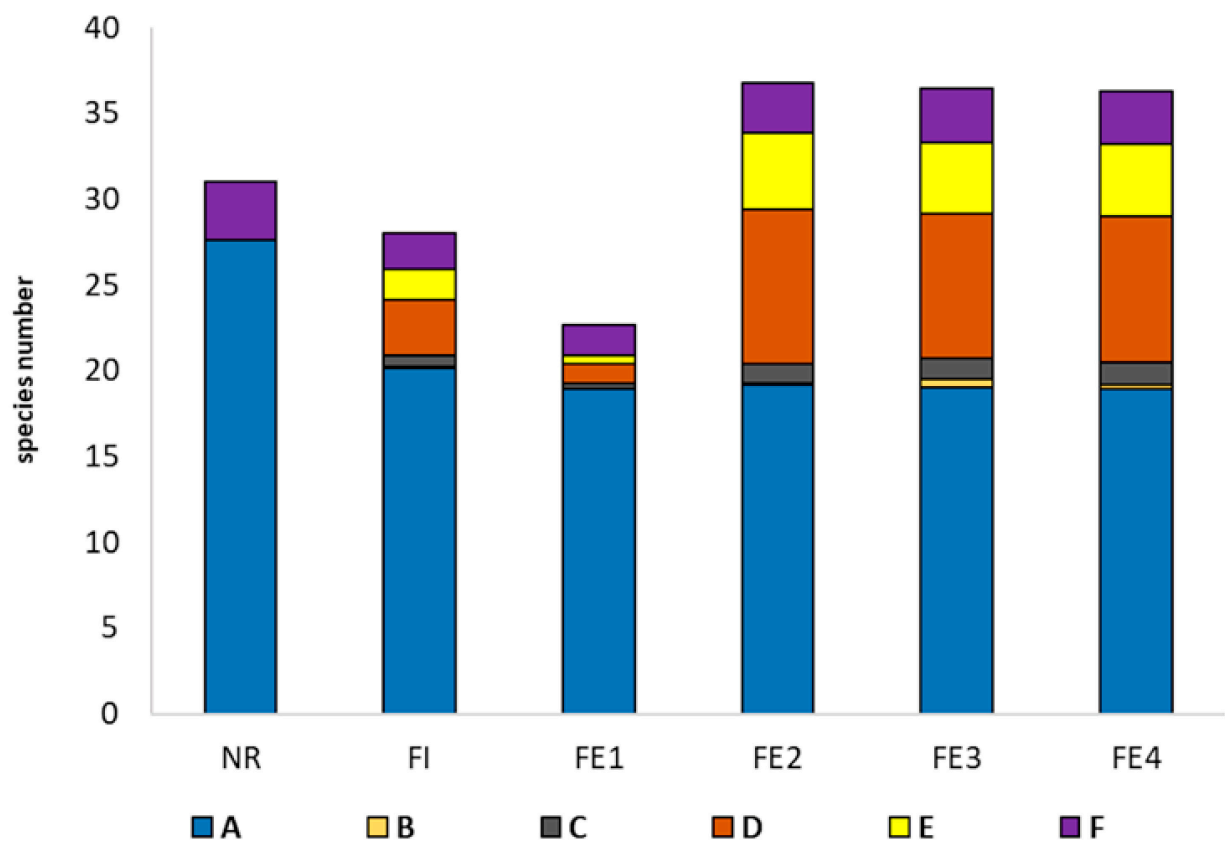

Figure 5. Average number of forest species, consistent species with Tilio-Carpinetum community (A), inconsistent forest species with Tilio-Carpinetum community (B), plant species belonging to shrub communities (C), plant species belonging to synanthropic communities (D), plant species belonging to meadows and trampled communities $(\mathbf{E})$, and accompanying species $(\mathbf{F})$ in the nature reserve (NR), forest interior (FI), forest ecotone adjacent to the forest part of the manor park (FE1), forest ecotone adjacent to the housing estates (FE2), forest ecotone adjacent to the road (FE3), and forest ecotone adjacent to the agriculture field (FE4).

The DCA analysis found one main gradient explaining $36.4 \%$ of total variance (the next axes explained $7.5 \%, 5.6 \%$ and $5.3 \%$ of the observed variance) (Figure 6). It corresponds to the gradient between plant species from synanthropic communities, disturbed communities on the left and natural forest on the right. The most disturbed ecotones occurred to be those adjacent to the housing estates (FE2) and to the agriculture field (FE4), a bit less disturbed was the ecotone adjacent to the road (FE3). The ecotone adjacent to the forest part of the manor park (FE1) proved to be the most similar to the nature reserve. The area inside the urban forest (FI) showed some variation. The species composition on some plots was more natural, like FE1, on other plots it was more disturbed like FE3. At the same time, species characteristic for the natural and disturbed habitats could be distinguished. Natural forests were characterized by the presence of Anemone ranunculoides, Luzula pilosa, Lathyrus vernus, Carex umbrosa, Viola mirabilis and Mercurialis perennis and disturbed ecotones by the presence of Convolvulus arvensis, Lysimachia nummularia, Impatiens parviflora, Chelidonium majus, and Chaerophyllum aromaticum. The full species list with first axis scores is presented in Appendix A. 


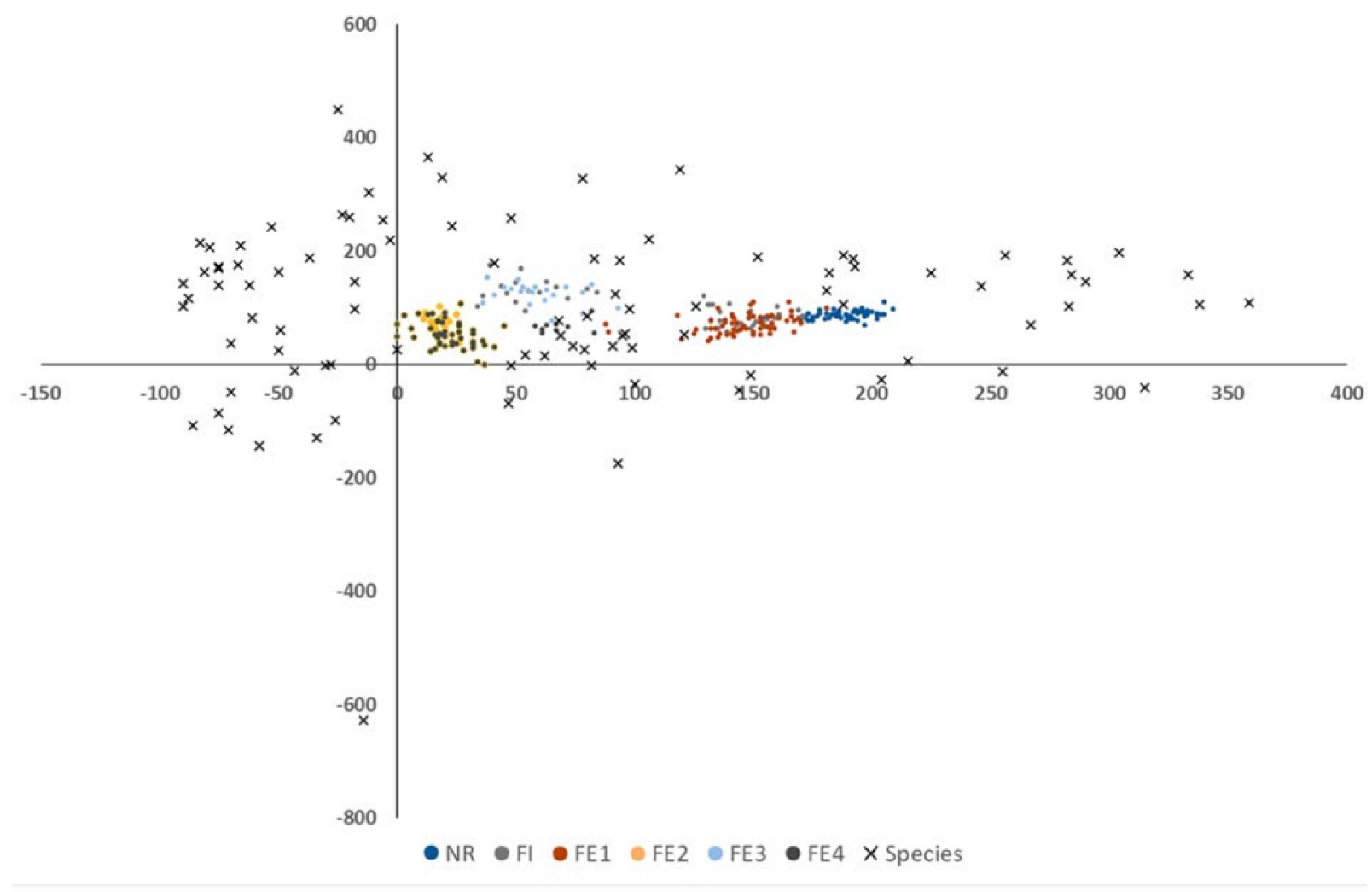

Figure 6. Detrended correspondence analysis (DCA) plots (color dots-plots (research areas), x-species, number at axis presented explained variance).

The study confirmed that different types of land use adjacent to the forest have an impact on the species composition in the undergrowth layer of forest ecotones. Our research distinguished plant species that belong not only to the forest community, but also to meadows, trampled and synanthropic communities. Furthermore, it proved that the agriculture field, road and the housing estates adjacent to the forest have a larger impact on the occurrence of inconsistent forest and non-forest plant species in forest ecotones than inside the urban forest and the nature reserve (hypothesis 1). It was confirmed that synanthropic plant species are strictly connected with changes of habitat conditions [50]. According to [51], inconsistent plant species are indicators of an anthropogenic impact on a habitat as also observed in the forest ecotones studied by us. Numbers of plants from Tilio-Carpinetum were similar in all types of forest ecotones, but the share of forest plants was the biggest in the forest ecotone adjacent to the manor park. The conducted study [43] demonstrated that manor parks could support forest and ancient forest plant species, provided their habitats were not strongly disturbed by anthropogenic impacts. From all types of land use adjacent to the forest, the forest part of the manor park is characterized by the management with the lowest impact by humans. The localization of the forest adjacent to the manor park provides better regeneration of natural undergrowth plant species in the forest ecotone. According to [52], regeneration and occurrence of native forest species depend on complex factors such as, for instance, intensity of disturbances, anthropogenic pressure, abiotic factors and weather conditions. Based on the DCA analysis, characteristic groups of plant species connected with the different types of land use (adjacent to forests) were distinguished (hypothesis 2). Plant species belonging to grass and synanthropic communities were typical for forest ecotones adjacent to the fields and the housing estates. Forest ecotone adjacent to the road also included these plants, but with a higher number of forest plant species than in the ecotones adjacent to the fields and the housing estates. Presumably, a higher occurrence of plant species tolerating disturbance such as trampling 
(e.g., Plantago major) was due to the fact that more visitors were entering that part of the forest, because of its location next to the housing estates. There were also plants found that are typical for disturbances of habitats as Urtica dioica, Lamium album, Oxalis fontana. Chelidonium majus and Lysimachia nummularia. Plants typical for disturbed forest habitat were observed in the forests by [15] and [53], too. Non-forest plant species are characterized by an easy seed dispersal mostly by wind, which could possibly explain their occurrence in the forests adjacent to the housing estates, fields and roads [54]. It was confirmed that vascular forest plants are more indicative for stability (occurring consistent forest plant species) of Tilio-Carpinetum communities in nature reserves than inside urban forests not being protected, and in ecotones (hypothesis 3; stability of plant community/ecosystem is explained by landscape ecology and means ability to self-regulation and lasting for a long time). According to [55], forest species, for example Carex umbrosa or Lathyrus vernus, are diagnostic species for stability of Tilio-Carpinetum habitat. Ref. [56] states that these species are very sensitive to changes in the habitat and occur only in slightly transformed habitats or natural stands. Native forest plants typical for Tilio-Carpinetum community grow in shaded stands and on rich soils [55]. This was also observed by [57] and [58]. It is confirmed that the studied nature reserve in Tarnów has got more proper habitat conditions for forest plants compositions inside the forest than the ecotones and the inside of the urban forest studied by us.

\section{Conclusions}

The ecotones of the studied urban forest support the growth of forest plant species consistent with Tilio-Carpinetum habitat and as well as ancient forest species. It should be noted that the types of land use adjacent to urban forest have a strong impact on vascular plant species compositions in ecotones. More plant species, like synanthropic and grasses, not typical for Tilio-Carpinetum forest, were growing on forest ecotones located closely to the disturbed areas. It was observed that the area with a lower anthropogenic pressure represented by the manor park had more positive impact on renewal of the ancient forest plants as well as forest species in Tilio-Carpinetum habitat. The highest number and share of forest plants were in the interior of the nature reserve, which was located at the outskirts of the city of Tarnów. This means proper management and statutory protection (high status such as nature reserve) are very useful for maintaining biodiversity and preserving the native, valuable forest plant species in urban landscape. In our opinion regulations should require local governments to ensure retention of a buffer zone around urban forests to maintain the highest possible number of plant species characteristic of natural habitats.

Author Contributions: Conceptualization, B.F.-P., B.Ż., M.O.; methodology, B.F.-P., M.O.; software, B.F.-P.; formal analysis, B.F.-P., B.Ż., M.O.; investigation, B.F.-P.; resources, B.F.-P.; data curation, B.F.-P.; writing—original draft preparation, B.F.-P., B.Ż., M.O.; writing—review and editing, B.F.-P., B.Ż., M.O.; visualization, B.F.-P., M.O. All authors have read and agreed to the published version of the manuscript.

Funding: This research received no external funding.

Institutional Review Board Statement: Not applicable.

Informed Consent Statement: Not applicable.

Data Availability Statement: Data is contained within the article or Appendix A. It is also available from the correspondence author (beata_fornal_pieniak@sggw.edu.pl).

Acknowledgments: We thank Axel Schwerk for valuable methodical remarks.

Conflicts of Interest: The authors declare no conflict of interest. 


\section{Appendix A}

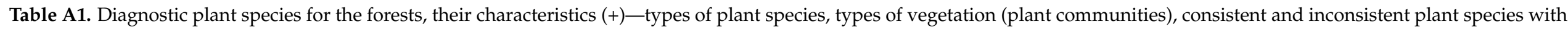
Tilio-Carpnietum, ancient or non-ancient species, and species scores for first ordination axis.

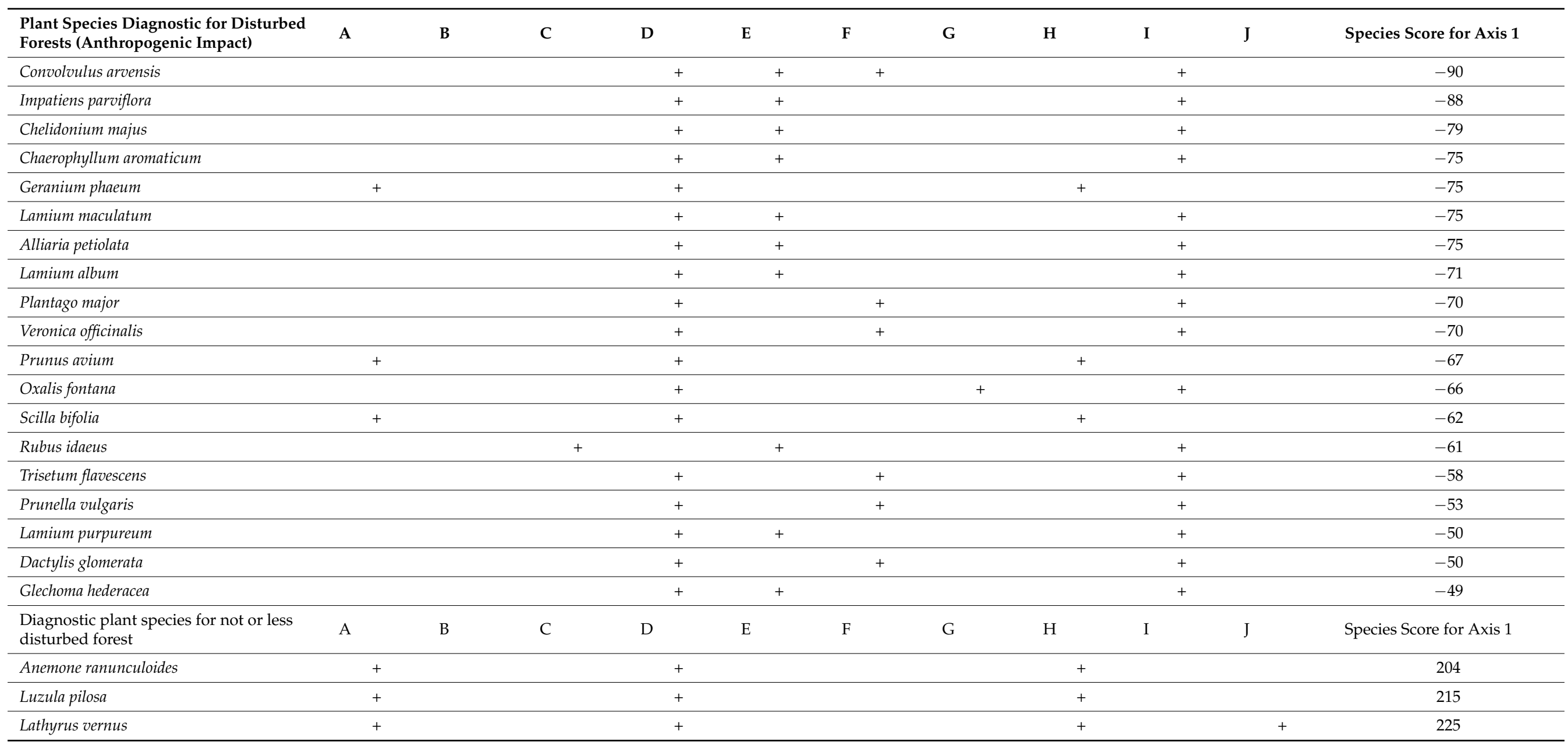


Table A1. Cont.

\begin{tabular}{|c|c|c|c|c|c|c|c|c|c|c|c|}
\hline $\begin{array}{l}\text { Plant Species Diagnostic for Disturbed } \\
\text { Forests (Anthropogenic Impact) }\end{array}$ & A & B & $\mathrm{C}$ & D & $\mathrm{E}$ & $\mathbf{F}$ & G & $\mathbf{H}$ & I & $\mathbf{J}$ & Species Score for Axis 1 \\
\hline Carex umbrosa & + & & & + & & & & + & & & 246 \\
\hline Viola mirabilis & + & & & + & & & & + & & + & 255 \\
\hline Mercurialis perennis & + & & & + & & & & + & & + & 256 \\
\hline Asarum europaeum & + & & & + & & & & + & & + & 267 \\
\hline Polygonatum multiflorum & + & & & + & & & & + & & + & 282 \\
\hline Oxalis acetosella & & & & + & & & & + & & + & 283 \\
\hline Galium mollugo & & & & + & & + & & & + & & 284 \\
\hline Stellaria holostea & + & & & + & & & & & + & + & 290 \\
\hline Peucedanum oreoselinum & & & & + & & + & & & + & & 304 \\
\hline Fagus sylvatica & + & + & & & & & & & + & & 315 \\
\hline Tilia tomentosa & & + & & & & & + & & + & & 333 \\
\hline Corylus avellana & + & + & & & & & & + & & + & 338 \\
\hline Sorbus aucuparia & & + & & & & & + & & + & & 359 \\
\hline Galium sylvaticum & & & & + & + & & & & + & & -43 \\
\hline Hedera helix & & & & + & & & + & + & & & -37 \\
\hline Crataegus monogyna & & & + & + & & & & & + & & -34 \\
\hline Geum urbanum & & & & + & + & & & & + & & -30 \\
\hline Geranium sylvaticum & & & & + & + & & & & + & & -28 \\
\hline Robinia pseudoacacia & & + & & & + & & & & + & & -26 \\
\hline Convallaria majalis & + & & & + & & & & & + & & -23 \\
\hline Ranunculus lanuginosus & + & & & + & & & & + & & & -20 \\
\hline Rosa rugosa & & & + & & & & & & + & & -18 \\
\hline Trientalis europaea & + & & & + & & & & & + & & -18 \\
\hline Veronica chamaedrys & & & & + & & & + & & + & & -14 \\
\hline Lapsana communis & 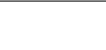 & & & + & 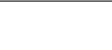 & & + & & + & & -12 \\
\hline
\end{tabular}


Table A1. Cont.

\begin{tabular}{|c|c|c|c|c|c|c|c|c|c|c|c|}
\hline $\begin{array}{l}\text { Plant Species Diagnostic for Disturbed } \\
\text { Forests (Anthropogenic Impact) }\end{array}$ & $\mathbf{A}$ & B & $\mathrm{C}$ & D & $\mathrm{E}$ & $\mathbf{F}$ & G & $\mathbf{H}$ & I & $\mathbf{J}$ & Species Score for Axis 1 \\
\hline Melampyrum nemorosum & + & & & + & & & & + & & + & -6 \\
\hline Moehringia trinervia & & & & + & & & + & & & & -3 \\
\hline Allium ursinum & + & & & + & & & & + & & & 0 \\
\hline Rubus alpinum & + & & & + & & & & + & & & 13 \\
\hline Fragaria vesca & + & & & + & & & & & + & & 19 \\
\hline Sambucus nigra & & & + & & & & & & + & & 23 \\
\hline Deschampsia flexuosa & & & & + & & + & & & + & & 41 \\
\hline Ficaria verna & + & & & + & & & & + & & & 47 \\
\hline Geranium robertianum & + & & & + & & & & + & & & 48 \\
\hline Populus alba & + & + & & & & & & & + & & 48 \\
\hline Tilia cordata & + & + & & & & & & + & & + & 54 \\
\hline Vinca minor & + & & & + & & & & + & & & 62 \\
\hline Pulmonaria officinalis & + & & & + & & & & + & & + & 68 \\
\hline Euonymus verrucosa & + & & + & & & & & + & & & 74 \\
\hline Hieracium murorum & + & & & + & & & & + & & & 78 \\
\hline Aegopodium podagraria & + & & & + & & & & & + & & 79 \\
\hline Impatiens noli-tangere & + & & & + & & & & & + & & 80 \\
\hline Milium effusum & + & & & + & & & & + & & + & 82 \\
\hline Dactylis polygama & + & & & + & & & & + & & + & 83 \\
\hline Corydalis cava & + & & & + & & & & + & & + & 91 \\
\hline Rubus caesius & & & + & & & & & & + & & 92 \\
\hline Ajuga reptans & + & & & + & & & + & + & & & 93 \\
\hline Ulmus laevis & + & + & & & & & & + & & & 94 \\
\hline Gagea lutea & + & & & + & & & & + & & + & 95 \\
\hline
\end{tabular}


Table A1. Cont.

\begin{tabular}{|c|c|c|c|c|c|c|c|c|c|c|c|}
\hline $\begin{array}{l}\text { Plant Species Diagnostic for Disturbed } \\
\text { Forests (Anthropogenic Impact) }\end{array}$ & $\mathbf{A}$ & B & $\mathrm{C}$ & $\mathbf{D}$ & E & $\mathbf{F}$ & G & $\mathbf{H}$ & $\mathbf{I}$ & $\mathbf{J}$ & Species Score for Axis 1 \\
\hline Acer platanoides & + & + & & & & & & + & & & 96 \\
\hline Acer campestre & + & + & & & & & & + & & + & 98 \\
\hline Poa nemoralis & + & & & + & & & & + & & + & 99 \\
\hline Maianthemum bifolium & + & & & + & & & & & + & & 100 \\
\hline Aesculus hippocastanum & & + & & & & & + & & + & & 106 \\
\hline Paris quadrifolia & + & & & + & & & & + & & & 119 \\
\hline Circaea lutetiana & + & + & & + & & & & + & & + & 121 \\
\hline Carpinus betulus & + & & & + & & & & + & & & 126 \\
\hline Taraxacum officinale & & & & + & & + & & . & + & & 144 \\
\hline Anemone nemerosa & + & & & + & & & & + & & + & 149 \\
\hline Stachys sylvatica & + & & & + & & & & + & & + & 152 \\
\hline Melica nutans & + & & & + & & & & + & & + & 181 \\
\hline Quercus robur & + & + & & + & & & & + & & & 182 \\
\hline Viola mirabilis & + & & & + & & & & + & & + & 188 \\
\hline Acer pseudoplatanus & + & + & & & & & & + & & & 192 \\
\hline Polygonatum odoratum & + & & & + & & & & & + & & 193 \\
\hline
\end{tabular}

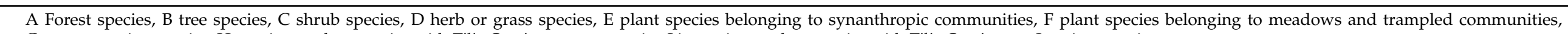
$\mathrm{G}$ accompanying species, H consistent plant species with Tilio-Carpinetum community, I inconsistent plant species with Tilio-Carpinetum, J ancient species. 


\section{References}

1. Florgård, C. Preserved and remnant natural vegetation in cities: A geographically divided field of research. Landsc. Res. 2007, 32, 79-94. [CrossRef]

2. Blinkova, O.; Shupova, T. Bird communities and vegetation composition in the urban forest ecosystem: Correlations and comparisons of diversity indices. Ekologia 2017, 36, 366-387.

3. Kolimenakis, A.; Solomou, A.D.; Proutsos, N.; Avramidou, E.V.; Korakaki, E.; Karetsos, G.; Tsagkari, K. The Socioeconomic Welfare of Urban Green Areas and Parks; A Literature Review of Available Evidence. Sustainability 2021, 13, 7863. [CrossRef]

4. Wajchman-Świtalska, S.; Zajadacz, A.; Lubarska, A. Therapeutic functions of forests and green areas with regard to the universal potential of sensory gardens. Environ. Sci. Proc. 2020, 3, 8.

5. Doimo, I.; Masiero, M.; Gatto, P. Forest and wellbeing: Bridging medical and forest research for effective forest-based initiatives. Forests 2020, 11, 791. [CrossRef]

6. Solomou, A.D.; Topalidou, E.T.; Germani, R.; Argiri, A.; Karetsos, G. Importance, utilization and health of urban forests: A review. Not. Bot. Horti Agrobot. Cluj-Napoca 2019, 47, 10-16. [CrossRef]

7. Bonilla-Duarte, S.; Gómez-Valenzuela, V.; Vargas-de la Mora, A.L.; García-García, A. Urban Forest Sustainability in Residential Areas in the City of Santo Domingo. Forests 2021, 12, 884.

8. Zhi-Ying, H.; Yeo-Chang, Y. Beijing resident's preferences of ecosystem services of urban forests. Forests 2021, 12, 14. [CrossRef]

9. Grima, N.; Corcoran, W.; Hill-James, C.; Langton, B.; Sommer, H.; Fisher, B. The importance of urban natural areas and urban ecosystem services during the COVID-19 pandemic. PLoS ONE 2020, 15, e243344. [CrossRef]

10. Wolf, K.L.; Lam, S.T.; McKeen, J.K.; Richardson, G.R.A.; van den Bosch, M.; Bardekjian, A.C. Urban Trees and Human Health: A Scoping Review. Int. J. Environ. Res. Public Health 2020, 17, 4371. [CrossRef]

11. Chiesura, A. The role of urban parks for the sustainable city. Landsc. Urban Plan. 2004, 68, 129-138. [CrossRef]

12. Baker, T.P.; Jordan, G.J.; Baker, S.C. Microclimatic edge effects in a recently harvested forest: Do remnant forest patches create the same impact as large forest areas? For. Ecol. Manag. 2016, 365, 128-136. [CrossRef]

13. Kolk, J.; Naaf, T. Herb layer extinction debt in highly fragmented temperate forests-Completely paid after 160 years? Biol. Conserv. 2015, 182, 164-172. [CrossRef]

14. Fornal-Pieniak, B.; Ollik, M.; Schwerk, A. Impact of different levels of anthropogenic pressure on the plant species composition in woodland sites. Urban For. Urban Green. 2019, 38, 295-304. [CrossRef]

15. Brunet, J.; Valtinat, K.; Mayr, M.L.; Felton, A.; Lindbladh, M.; Bruun, H.H. Understory succession in post-agricultural oak forests: Habitat fragmentation affects forest specialists and generalists differently. For. Ecol. Manag. 2011, 262, 1863-1871. [CrossRef]

16. Swallow, K.A.; Wood, M.J.; Goodenough, A.E. Relative contribution of ancient woodland indicator and non-indicator species to herb layer distinctiveness in ancient semi-natural, ancient replanted, and recent woodland. Appl. Veg. Sci. 2020, 23, 471-481. [CrossRef]

17. Sukopp, H. Human-caused impact on preserved vegetation. Landsc. Urban Plan. 2004, 68, 347-355. [CrossRef]

18. Krzymowska-Kostrowicka, A. Development and tourist traffic. Geogr. Work. 1988, 147, 87-107.

19. Whinam, J.; Chilcott, N.M. Impacts after four years of experimental trampling on alpine/sub-alpine environments in western Tasmania. J. Environ. Manag. 2003, 67, 339-351. [CrossRef]

20. Jahani, A.; Goshtasb, H.; Saffariha, M. Tourism impact assessment modeling of vegetation density for protected areas using data mining techniques. Land Degrad. Dev. 2020, 31, 1502-1519. [CrossRef]

21. Hofmeister, J.; Hošek, J.; Brabec, M.; Hédl, R.; Modrý, M. Strong influence of long-distance edge effect on herb layer vegetation in forest fragmentations in and agricultural landscape. Perspect. Plant Ecol. Evol. Syst. 2013, 15, 293-303. [CrossRef]

22. Hegetschweiler, K.T.; van Loon, N.; Ryser, A.; Rusterholz, H.P.; Baur, B. Effects of fireplace use on forest vegetation and amount of woody debris in suburban forests in northwestern Switzerland. Environ. Manag. 2009, 43, 299-310. [CrossRef]

23. Matuszkiewicz, J.M. Analiza zmienności przestrzennej runa w strefie kontaktowej dwóch fitocenoz. (Spatial changeability analysis in contact zone of two phytocoenosis). Phytocoenosis 1972, 12, 22-150.

24. Falińska, K. Modification of plant population in forest ecosystems and their ecotones. Pol. Ecol. Stud. 1979, 1, 89-150.

25. Falińska, K. Ekologia Roślin. [Plant Ecology]; Wydawnictwo Naukowe PWN: Warszawa, Poland, 1997; ISBN 83-01-12065-7.

26. Veleskin, D.V.; Shavnin, S.A.; Vorobeichik, E.L.; Galako, V.A.; Vlasenco, V.E. Edge Effects on Pine Stands in a Large City. Russ. J. Ecol. 2017, 48, 499-506. [CrossRef]

27. Guirado, M.; Pino, J.; Rodà, F. Understorey plant species richness and composition in metropolitan forest archipelagos: Effects of forest size, adjacent land use and distance to the edge. Glob. Ecol. Biogeogr. 2006, 15, 50-62. [CrossRef]

28. Hamberg, L.; Lehvävirta, S.; Malmivaara-Lamsa, M.; Rita, H.; Kotze, D.J. The effects of habitat edges and trampling on understorey vegetation in urban forests in Helsinki, Finland. Appl. Veg. Sci. 2008, 11, 83-98. [CrossRef]

29. Żarska, B. Wpływy ekotonowe w roślinności strefy brzegowej lasów a kształtowanie zalesień. [Ecotone effects in vegetation in marginal zones of forests versus afforestation planning]. Ochr. Śr. I Zasobów Nat. [Prot. Environ. Nat. Resour.] 1994, 8, 13-25.

30. Żarska, B. Zmiany roślinności w strefie brzegowej lasów. [Vegetation changes in marginal zones of forests]. Ochr. Śr. I Zasobów Nat. [Prot. Environ. Nat. Resour.] 1997, 12, 105-115.

31. Lehvävirta, S.; Vilisics, F.; Hamberg, L.; Malmivaara-Lämsä, M.; Kotze, J.D. Fragmentation and recreational use affect tree regeneration in urban forests. Urban For. Urban Green. 2014, 13, 869-877. [CrossRef] 
32. Wuyts, K.; De Schrijver, A.; Verheyen, K. The importance of forest type when incorporating forest edge deposition in the evaluation of critical load exceedance. iForest-Biogeosciences For. 2009, 2, 43-45. [CrossRef]

33. Gonzalez, P.; Neilson, R.P.; Lenihan, J.M.; Drapek, R.J. Global patterns in the vulnerability of ecosystems to vegetation shifts due to climate change. Glob. Ecol. Biogeogr. 2010, 19, 755-768. [CrossRef]

34. Godefroid, S.; Koedam, N. Urban plant species patterns are highly driven by density and function of built-up areas. Landsc. Ecol. 2007, 22, 1227-1239. [CrossRef]

35. Mestre, L.; Toro-Manríquez, M.; Soler, R.; Huertas-Herrera, A.; Martínez-Pastur, G.; Lencinas, M.V. The influence of canopy layer compositionon understory plant diversity in southern temperate forests. For. Ecosyst. 2017, 4, 6. [CrossRef]

36. Cadenasso, M.L.; Pickett, S.T.A.; Weathers, K.C.; Jones, C.G. A Framework for a Theory of Ecological Boundaries. BioScience 2003, 53, 750-758. [CrossRef]

37. Harper, K.A.S.; MacDonald, E.; Burton, P.J.; Chen, J.; Brosofske, K.D.; Sauders, S.C.; Euskirchen, E.S.; Roberts, D.; Jaiteh, M.S.; Esseen, P.A. Edge Influence on Forest Structure and Composition in Fragmented Landscapes. Conserv. Biol. $2005,19,768-782$. [CrossRef]

38. Gutsch, M.; Lasch-Born, P.; Kollas, C.; Suckow, F.; Reyer, C.P.O. Balancing trade-offs between ecosystem services in Germany's forests under climate change. Environ. Res. Lett. 2018, 13, 045012. [CrossRef]

39. Langmaier, M.; Lapin, K. A Systematic Review of the Impact of Invasive Alien Plants on Forest Regeneration in European Temperate Forests. Front. Plant Sci. 2020, 11, 524969. [CrossRef] [PubMed]

40. Jarek, S.; Stachurska-Swakoń, A. Flora okolic Tarnowa (Kotlina Sandomierska) [The flora of the Tarnów area (Sandomierska Basin)]. Fragm. Florist. Geobot. Pol. 2016, 23, 243-254.

41. Matuszkiewcz, W. Przewodnik do Oznaczania Zbiorowisk Roślinnych Polski (Guide for Determining Plant Communities in Poland); Wydawnictwo Naukowe PWN: Warszawa, Poland, 2012.

42. Fijałkowski, D.; Kseniak, M. Parki Wiejskie Lubelszczyzny. Stan, Ochrona i Rewaloryzacja Biocenotyczna; PWNL: Warsaw, Poland, 1982.

43. Fornal-Pieniak, B.; Ollik, M.; Schwerk, A. Do Adjacent Forests Affect the Regeneration of Oak-Hornbeam and Ancient Forest Plant Species in Manor Parks in Poland? Forests 2021, 12, 538. [CrossRef]

44. Braun-Blanquet, J. Pflanzensoziologie, 2nd ed.; Springer: Wiena, Austria, 1951.

45. Webb, J.C.; Goodenough, A.E. Questioning the reliability of "ancient" woodland indicators: Resilience to interruptions andpersistence following deforestation. Ecol. Indic. 2018, 84, 354-363. [CrossRef]

46. Dzwonko, Z.; Loster, S. Wskaźnikowe gatunki roślin starych lasów i ich znaczenie dla ochrony przyrody i kartografii roślinności. Typologia zbiorowisk i kartografia roślinności w Polsce. Pr. Geogr. 2001, 178, 119-132.

47. Matuszkiewicz, W. Teoretyczno-metodyczne podstawy badań roślinności jako elementu krajobrazu i obiektu użytkowania rekreacyjnego. (Theoretical and methodological foundations of vegetation research as an element of landscape and an object of recreational use). Wiadomości Ekol. (Ecol. News) 1974, 20, 3-13.

48. Van der Maarel, E. Transformation of cover-abundance values in phytosociology and its effects on community similarity. Vegetatio 1979, 39, 97-114. [CrossRef]

49. Lawes, S.M.J.; Lamb, B.C.C.; Bouderau, S. Area-but not edge-Effect on woody seedling abundance and species richness in old Afromontane forest fragments. J. Veg. Sci. 2005, 16, 363-372. [CrossRef]

50. Gawenda-Kempczyńska, D.; Paszek, I.; Załuski, T. Regeneration of vegetation in manor park in Laskowice (Dąbrowa Forest District). Ecol. Quest. 2017, 27, 39-52. [CrossRef]

51. Pyšek, P.; Richardson, D.M.; Williamson, M. Predicting and explaining plant invasions through analysis of source area floras: Some critical considerations. Divers. Distrib. 2004, 10, 179-187. [CrossRef]

52. Kellner, K.K.; Swihart, R.K. Timber harvest and drought interact to impact oak seedling growth and survival in the Central Hardwood Forest. Ecosphere 2016, 7, e01473. [CrossRef]

53. Fornal-Pieniak, B.; Ollik, M.; Scherk, A. Vascular flora of urban forests in a medium-sized city in Poland: Comparison with nature reserves in the city's surrounding. Landsc. Res. 2021, 46, 246-260. [CrossRef]

54. Rehm, E.M.; Thomas, M.; Yelenik, S.; Bouck, D.; D'Antonio, C. Bryophyte abundance, composition and importance to woody plant recruitment in natural and restoration forest. For. Ecol. Manag. 2019, 444, 405-413. [CrossRef]

55. Brunet, J.; De Frenne, P.; Holmström, E.; Mayr, M.L. Life-history traits explain rapid colonization of young post-agricultural forests by understory herbs. For. Ecol. Manag. 2012, 278, 55-62. [CrossRef]

56. Dzwonko, Z. Rośliny runa wskaźnikami pochodzenia i przemian lasów [Herb layer plants as indicators of woodland origin and changes]. Studia I Mater. CEPL 2015, 42, 27-37. Available online: http://cepl.sggw.pl/sim/pdf/sim42_pdf/Dzwonko.pdf (accessed on 17 August 2021).

57. Wulf, M. Preference of plant species for woodlands with differing habitat continuities. Flora-Morphol. Distrib. Funct. Ecol. Plants 2003, 198, 444-460. [CrossRef]

58. Fornal-Pieniak, B.; Ollik, M. Diversity of flora in the undergrowth of park afforestations, rural plantings and oak-hornbeam forests. Folia For. Polonica. Ser. A 2013, 55, 132-136. [CrossRef] 